顎関節症様症状をめって初発した後臼㐘部腺様囊胞癌の 1 例

井口次夫・原田利夫・佐野和生

井上賢悟・佐々木元賢

\title{
Retromolar adenoid cystic carcinoma initially manifested as temporomandibular arthrosis: Report of a case
}

\author{
Tsugio Inokuchi - Toshio Harada - Kazuo Sano
}

Kengo Inoue - Motomasa SASAKI

緒

$\overline{\overline{\overline{⿳ 亠 口}}}$

口腔領域の腺様整胞癌は, 特にまれな疾患ではない. しかし，発育が比較的緩慢であったり，潰瘍を形成しな いケースもみられることから，ややもすれば誤った診断 を下しやすい，加えて，このような悪性新生物が，咀嚼 筋群に浸潤した場合には，Temporomandibular Arthrosis'1), あるいは近年, 提唱されている MPD syndrome ${ }^{2)}$ 様の症状を呈するなど，わたくしたち臨床医を惑わすこ とがある。

最近，わたくしたらは，顎関節症様症状をもって初発

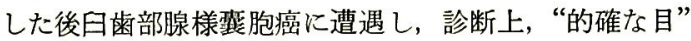
とあらゆる角度からの症状の検討が要求されるという教 訓を得たので報告する。

症例

\section{患 者: 48 歳 \\ 初 診: 昭和53年 2 月—.}

主 訴: 開口障害, 開口時痛, 左側顔面痛ならびに左 側下顎後臼崡部より左側翼突下顎壁部にかけての違和感 と接触痛。

既往歴：昭和29年に虫垂切除術を受けた。昭和50年頃 より高血王症のために内科に通院し降圧剤を服用中であ る.

現病歴： 2 年前より, 口腔清掃時に, 左側翼突下顎壁 部に接触痛を覚学るようになり, その後, 同部の鈍痛, 違和感も感じはじめた。 また，朝起床時，開口障害もみ

長崎大学医学部口腔基礎医学講坐 - 荘科口腔外科

(顎・顔面) 第 2 診療科（主任：佐々木元賢教授）

Department of Stomatology, Clinic of Maxillofacial and Oral Surgery, Nagasaki University School of medicine(Chief: Prof. Motomasa Sasaki)

受付日：昭和54年 9 月 3 日

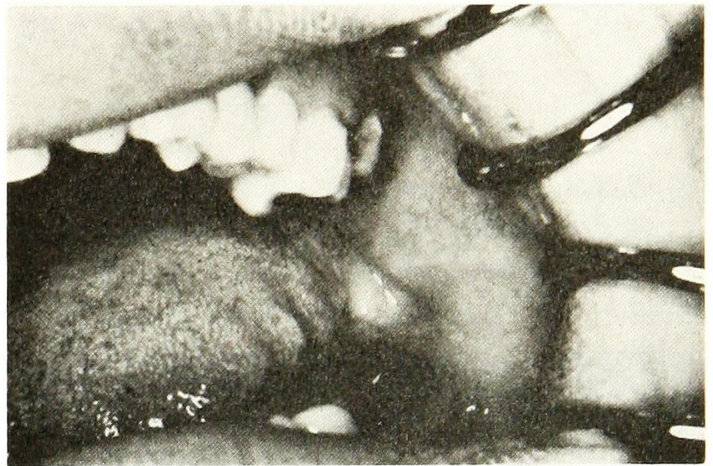

写真 1 口腔内所見 左側翼突下箕璧部

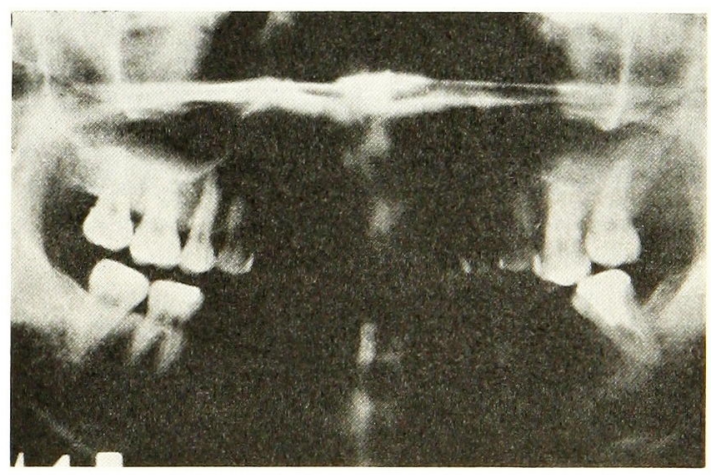

写真 2 X線所見 左㑡上顎結節辺縁の骨吸収像

られるようになってきた。そこで，顎関節症の疑いの下 に，消炎阂の投与や光線療法を受けた。しかし，次第に 症状増悪し，開口障害も顕著になり，不眠を訴えるな ど, 不安を覚えるようになったので, 某整形外科を経由 して当科を訪れた。

現 症：体格，栄差状態ともに中等度で，顔色はやや 
表 1 臨床 検 查成 績

\begin{tabular}{|c|c|c|c|c|}
\hline $\mathrm{WBC}$ & $5,800 / \mathrm{mm}^{3}$ & Seru & & \\
\hline $\mathrm{RBC}$ & $451 \times 10^{4} / \mathrm{mm}^{3}$ & $\mathrm{Na}$ & $144 \mathrm{mEq} / l$ & \\
\hline $\mathrm{Hb}$ & $12.3 \mathrm{~g} / \mathrm{d} l$ & $\mathrm{~K}$ & 2.3 & \\
\hline $\mathrm{Ht}$ & $36.7 \%$ & $\mathrm{Cl}$ & 98 & \\
\hline platelet & $10.2 \times 10^{4} / \mathrm{mm}^{3}$ & $\mathrm{Ca}$ & 9.3 & \\
\hline Bleeding time & $2 \mathrm{~min}$. & $\mathrm{P}$ & 3.6 & \\
\hline \multirow[t]{3}{*}{ Coagulation time } & $7.5 \mathrm{~min}$. & GOT & 25 & \\
\hline & & GPT & 21 & \\
\hline & & TTT & 2.3 & \\
\hline Urinalysis & & Kunkel & 5.9 & \\
\hline Protein (-) & & BUN & $14 \mathrm{mg} / \mathrm{d} l$ & \\
\hline Sugar $(-)$ & & Ch-E & 0.79 & \\
\hline \multirow[t]{6}{*}{ Keton (-) } & & $\mathrm{LDH}$ & 321 & \\
\hline & & Creatin & & $0.5 \mathrm{mg} / \mathrm{d} l$ \\
\hline & & Mucop & & $196 \mathrm{mg} / \mathrm{d} l$ \\
\hline & & Total & & $7.4 \mathrm{~g} / \mathrm{d} l$ \\
\hline & & Total & & $206 \mathrm{mg} / \mathrm{d} l$ \\
\hline & & W-R C & & \\
\hline
\end{tabular}

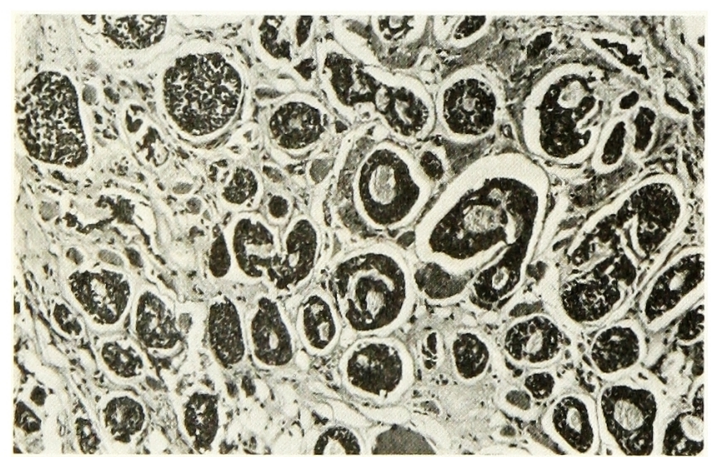

写真 3 病理組織像 腺様蘘胞癌 (H-E 染色)
䝯血性，顔貌は左右対称であった，左側煩部の腫脤，所 属リンパ節の腫脹，圧痛は認められなかったが，左側上 頓部より耳下腺咬笳部伛けての疼痛が認められた。

口腔内所見では，左側下顎後曰苗部上り左側翼突下顎 譬部にかけての違和感と圧痛があったが，同部の表面は 正常な粘膜色を呈し, 腫瘤や潰瘍の形成は認められなか った（写真1）。 また，咬合関係の異常は認められなか った。 たた，下䫓枝前縁部に沿って，健側に比べて境界 不明膫な板状のわずかな硬結が認められた。

$\mathbf{X}$ 線所見：左側上顎結節辺縁に不明膫なわずかな骨吸 収所見が認められるが，この所見は，健側と比較しても 明膫とはいいがたい（写真 2)。靧関節部X線写真には,

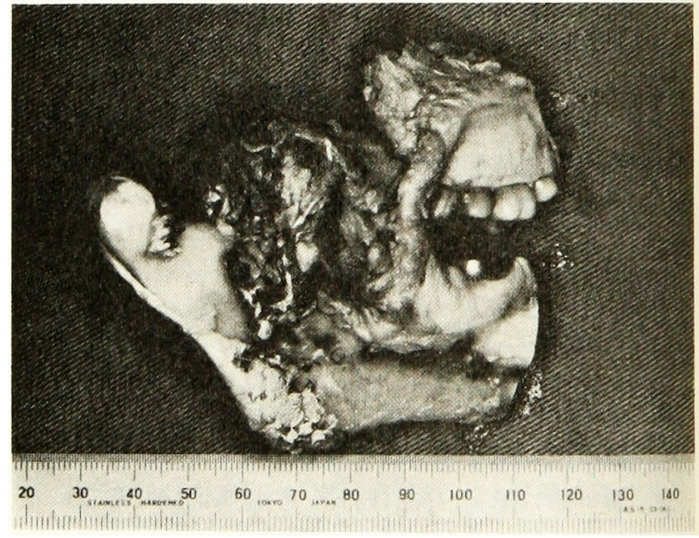

写真 4 摘出尰溜（舌側面より）

異常が認められず，また，胸部 $\mathrm{X}$ 線写真にも異常は認め られなかった。

臨床検查成績 : 表 1 のごとくで, 血清カリウムの低下 以外は, 血液一般, 尿検査, 血清電解質, その他の生化 学的検查成繢, 梅毒血清反応，心電図には異常を認めな かった.

病理組織学的診断：以上の所見より,左側後臼歯部の 悪性腫痬を疑い，左側翼突下罘譬部より切開を加兄，下 䫇枝前縁部で組織片を採取し, 検索の結果, 腺様䤤胞癌 と診断した（写真了）.

処置ならびに経過：術前検查において，血清カリウム が低值を示したので，補正したのち，炤和 53 年 4 月 5 


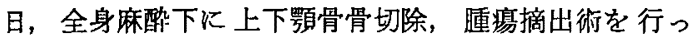
た.

上顎骨は，第 2 小曰歯部から後方，下顎骨は，第 1 大 曰齿から後方を部分的に切断するとともに，翼口蓋窩部 から, 内・外側翼突筋, 咬筋, 軟口蓋, 口蓋扁桃, 頓粘 膜の一部を含めて，腫瘍を一塊として切除摘出した。

腫鈞の大きさは，左側下顎第 2 大曰歯部より下顎骨後 縁まで，上方は䫟関節頭，下方は下靧骨下縁にわたるも ので，摘出物は $7 \times 5 \times 3.5 \mathrm{~cm}$ であった（写真 4 ）。

術後, 化学療法として, フトラフール坐薬総量 $21 \mathrm{~g}$ を 投与した，その後，退院，経過良好で，術後 1 年 3 か月 になるが，現在のところ，再発，転移の徵候は認められ ない.

摘出腫瘍の病理組織学的所見：割面肉眼所見；摘出物 割面は白色均質性で側頭筋下部，咬筋，内側翼突筋への 浸潤が認められた。

組織学的所見; 極めて特徽のある管状棈造を呈してい る、管腔は篩目状に分かれており，癌細胞はいずれる小 型で濃染する核と比較的明るい小さな細胞質を有してい る、ところどころ管腔内の粘液様物質も認められる（写 真了).

考察

この症例では, 開口障害, 開口時痛, 左側上頓部より 耳下腺咬筋部にかけての顔面痛があり，口腔内では，左 側下顎後曰歯部より左側翼突下顎譬部にかけての圧痛が 喼められた。 また患者は，朝起床時，努力しなければロ を開けることが不可能となり，顔面痛は次第に増悪し て，その不安から不眠に陥るなど，多様な症状を呈する に至った.

しかしながら䫇関節部には，視診，触診およびX線検 查でる，器質的変化は認められず，また口腔内外に明ら

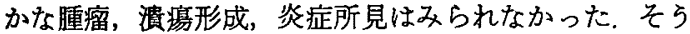
いらことから，顎関節症が疑われたのであろう。このこ とは MPD syndrome として処䈯中の患者で番咽頭腺癌 が発見された症例報告3)，あるいは Costen's syndrome として 処置中の患者で，腺癌が顎関節部に浸潤した 報 告)からもらなずける。
しかし，第 1 に詳細なX線診查の結果，左側上顎結節 辺縁に，健側と比較した場合，それほど明膫ではない がわずかな骨吸収所見が認められたこと，また第 2 に 下罘枝前縁部に沿って，健側に比べて境界不明瞭な板状 のわずかな硬結が認められたこと，この 2 点から，悪珄 腫湯の存在が疑われ，生検を行い腺様整胞癌と診断し た

また術後，腫湟割面から側頭筋，咬筋，内側翼突筋へ の癌の浸潤が認められた。癌の咀嚼筋への浸潤が，開口 障害の原因となることは当然であり，顔面痛などの多様 な症状を併発したものであろう。

ここに，腺系癌は発育が比較的緩慢であったり，潰瘍 を形成しないヶースむみられることから，診断上，“的 確な目”之あらゆる角度からの症状の検討が要求される ということを痛感し報告した。

結

語

顎関節症様症状をもって初発した症例で，咀嚼筋に浸 潤した腺様翼胞癌を発見した，癌の咀嶰筋への浸潤によ り，多様な症状が発現したと考えられるが，診断上， “的確な目”とあらゆる角度からの症状の検討が要求さ れるといら教訓を得たので報告した。

本論文の要旨は第34回日本口腔外科学会九州地方部会 （昭和54年 2 月 17 日，於鹿児島）に打いて発表した。

\section{引 用 文 献}

1) Schwartz, L.L.: Pain associated with the temporomandibular joint. JADA 51: 3941955.

2) Shafer, W.G., et al.. A textbook of oral pathology. ed 3, W.B. Saunders Co, Philadelphia, London, Toronto, 1974, p 661.

3) Sharav, Y., et al.. Nasopharyngeal tumor initially manifested as myofascial pain dysfunction syndrome. Oral Surg 44: 541977.

4) Thoma, K.H.: Oral Surgery. ed 5, The CV Mosby Co, Saint Louis, 1969, p 696. 